\title{
UJI EFEK ANTIBAKTERI JAMUR ENDIFIT PADA DAUN MANGROVE Sonneratia alba TERHADAP BAKTERI UJI Staphylococcus aureus DAN Escherichia coli
}

\author{
Dwilestari \\ Henoch Awaloei \\ Jimmy Posangi \\ Robert Bara
}

\author{
${ }^{1}$ Kandidat Skripsi Fakultas Kedokteran Universitas Sam Ratulangi Manado \\ Bagian Farmakologi dan Terapi Fakultas Kedokteran, Universitas Sam Ratulangi, Manado \\ Email: tarimahulette@gmail.com
}

\begin{abstract}
Endophytic fungi is a species of fungi which life on plant tissue system. Endophytic fungi can be isolated from the roots, stems and leave of the plant. Endophytic fungi can produce a substance potencial to be antibacteria. This research aimed to test the presence of antibacterial effect on an isolated leaf of mangrove plant Sonneratia alba towards Staphylococcus aureus and Escherichia coli. The method that is used for the antibacterial activity test, done by putting mycelia of endophytic fungi in combination media that has been smeared with Staphylococcus aureus and Escherichia coli. Obtained from research that has been made, it conducted two species of endophytic fungi that isolated from mangrove plant leaf Sonneratia alba. Both endophytic fungi has effect as antibacteria against Staphylococcus aureus and Escherichia coli, but the second type of endophytic fungi has more effective and stronger antibacterial effect compare to endophytic fungi type I and positive control.
\end{abstract}

Keywords: antibacterial, endophytic fungi, mangrove Sonneratia alba

\begin{abstract}
Abstrak: Jamur endofit adalah jamur yang terdapat dalam sistem jaringan tumbuhan. Jamur endofit dapat diisolasi dari akar, batang dan daun tumbuhan. Jamur endofit dapat menghasilkan senyawa yang berpotensi sebagai antibakteri. Penelitian ini bertujuan untuk mengetahui ada tidaknya efek antibakteri jamur endofit daun Sonneratia alba terhadap bakteri Staphylococcus aureus dan Escherichia coli. Metode yang digunakan untuk uji antibakteri dilakukan dengan cara menempelkan miselia jamur endofit pada media agar kombinasi yang telah dioleskan bakteri uji. Dari penelitian yang dilakukan diperoleh dua jenis jamur endofit yang diisolasi dari daun tumbuhan mangrove Sonneratia alba. Kedua jamur endofit memiliki efek sebagai antibakteri terhadap kedua bakteri uji akan tetapi jamur endofit tipe II memiliki efek antibakteri yang lebih baik dibandingkan dengan jamur endofit tipe I dan kontrol positif.
\end{abstract}

Kata kunci: antibakteri, jamur endofit, daun Sonneratia alba

Tanaman obat telah lama diketahui menjadi salah satu sumber yang sangat penting dalam upaya pengobatan dan upaya mempertahankan kesehatan masyarakat. Di beberapa negara Asia dan Afrika, sekitar $80 \%$ penduduk yang hidup di pedesaan bergantung pada pengobatan tradisional untuk perawatan kesehatan primer. ${ }^{1,2}$
Sonneratia alba merupakan salah satu jenis mangrove yang memiliki potensi sebagai bahan obat. Masyarakat pesisir pantai di pulau Mantehage menggunakan bahan dari tumbuhan bakau bergenus Sonneratia untuk menyembuhkan nyeri otot, sakit pinggang, rematik, malaria, luka, tuberculosis (TBC) dan sebagai spermisida. ${ }^{3}$ 
Mangrove merupakan tumbuhan yang kaya akan senyawa bioaktif. Senyawa bioaktif yang terdapat dalam bagian-bagian mangrove tidak selalu berasal dari tanaman mangrove itu sendiri, tetapi dapat berasal dari organisme lain yang mensintesis bioaktif tersebut di dalam bagian mangrove. Berdasarkan asumsi ini maka dapat diduga bahwa kemungkinan terdapat jamur atau bakteri endofit yang mendiami tumbuhan tersebut dan berperan sebagai penghasil bioaktif yang sebenarnya. Studi terakhir dari Ananda dan Sridhar (2002) menunjukkan bahwa tumbuhan mangrove adalah sumber yang kaya akan jamur endofit. ${ }^{4}$

Jamur endofit adalah jamur yang terdapat dalam sistem jaringan tumbuhan. Jamur endofit dapat diisolasi dari akar, batang dan daun tumbuhan. Tanaman sebagai salah satu sumber makanan untuk pertumbuhan dan perkembangbiakan mikroorganisme endofit. Endofit mampu membuat kembali nutrisi dari tanaman dengan cara menghasilkan senyawa khusus, seperti metabolisme sekunder, untuk melindungi inangnya dari serangan patogen. Jamur ini menginfeksi tumbuhan sehat pada jaringan tertentu dan berpotensi mikotoksin, enzim, serta antibiotika. ${ }^{5-7}$

Berdasarkan hal di atas, penulis tertarik untuk melakukan penelitian mengenai efek antibakteri jamur endofit pada daun mangrove Sonneratia alba dan akan menguji apakah jamur endofit pada daun mangrove tersebut dapat menghambat pertumbuhan bakteri Staphylococcus aureus dan Escherichia coli.

\section{METODE PENELITIAN}

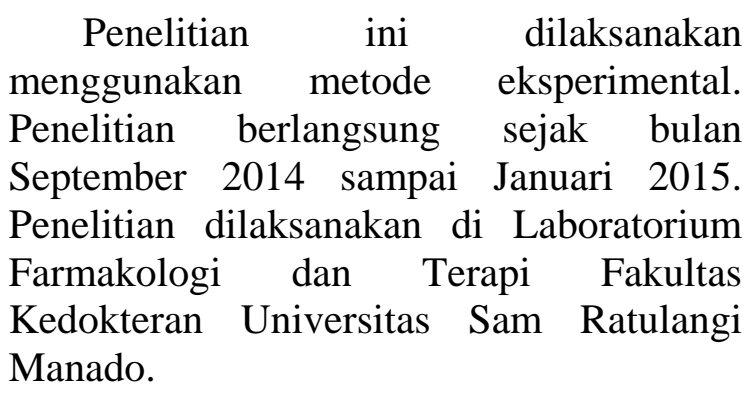

\section{Alat dan Bahan}

Alat-alat yang digunakan dalam penelitian ini yaitu: cawan petri, tabung reaksi, pinset, kapas lidi steril, oven, inkubator, api bunsen, jarum ose, tabung reaksi, tabung Erlenmeyer, autoclave, gunting, spidol, dan sarung tangan.

Bahan-bahan yang digunakan dalam penelitian ini yaitu: daun mangrove Sonneratia alba, bakteri Staphylococcus aureus, bakteri Escherichia coli, kapas steril, MEA (Malt Extract Agar), alkohol 70\%, agar plain, akuades, NA (Nutrient Agar), BHI (Brain Heart Infusion), MHA (Mueller Hinton Agar).

\section{Isolasi Jamur Endofit}

Alat-alat yang digunakan dalam penelitian ini disterilkan dalam oven pada suhu $170 \circ \mathrm{C}$ selama \pm 1 jam (sterilisasi kering). Media disterilkan dalam autoclave pada suhu $1210 \mathrm{C}$ selama 15 menit (sterilisasi basah). Daun mangrove jenis Avicennia marina diambil dan dibersihkan. Daun, pinset dan gunting direndam dalam larutan alkohol 70\% selama 10 detik untuk menghindari kontaminasi dari bakteri. Daun mangrove tersebut digunting membentuk persegi sebanyak 4 buah. Potongan tersebut ditanam pada media agar yang dibuat dari MEA (Malt Extract Agar) dan Agar plain di dalam cawan petri. Kloramfenikol $\quad 0,2 \mathrm{~g} / \mathrm{ml}$ sebelumnya ditambahkan ke dalam media agar untuk mencegah pertumbuhan bakteri lainnya. Cawan petri yang berisi daun mangrove tersebut ditutup, kemudian disimpan pada suhu kamar $\left(25^{\circ} \mathrm{C}\right)$ selama $2 \times 24$ jam untuk menumbuhkan jamur. Setelah 2x24 jam, akan terlihat pertumbuhan dari jamur di sekitar daun pada media agar. Setiap daun mangrove yang ditanam dapat menghasilkan beberapa pertumbuhan jamur endofit yang berbeda.

\section{Pemurnian Jamur Endofit}

Jamur endofit yang sudah tumbuh diambil sebagian dari miselia jamur tersebut pada permukaan agar dengan menggunakan kawat ose steril dan dipindahkan ke media MEA (Malt Extract Agar) lainnya dengan maksud untuk memurnikan pertumbuhan jamur endofit. 
Hal ini dilakukan pada setiap jamur endofit yang secara morfologi berbeda yang tumbuh pada daun mangrove tersebut. Pemurnian ini bertujuan untuk memisahkan koloni endofit dengan morfologi berbeda untuk dijadikan isolat tersendiri. Disimpan pada suhu ruangan selama 2x24 jam.

\section{Penyiapan Media Agar Miring dan Bakteri Uji}

Nutrient Agar (NA) ditimbang sebanyak 2,3 gram dan dilarutkan dalam 100 ml akuades. Media kemudian disterilisasi dalam autoclave pada suhu $121^{0} \mathrm{C}$ selama 15 menit. Selanjutnya media dituang dalam tabung reaksi sebanyak $7 \mathrm{ml}$ dan dibiarkan mengeras dengan kemiringan $15^{\circ}$. BHI (Brain Heart Infusion) ditimbang sebanyak 3,7 gram kemudian dilarutkan dalam $100 \mathrm{ml}$ akuades. Media disterilisasi dengan autoclave pada suhu $121^{\circ} \mathrm{C}$ selama 15 menit. Media selanjutnya dituang ke tabung reaksi sebanyak $5 \mathrm{ml}$ untuk selanjutnya digunakan sebagai media suspensi bakteri. Bakteri yang dikultur pada agar miring diambil dengan kawat ose steril dan dimasukkan ke dalam media BHI. Suspensi bakteri kemudian digoreskan dengan kawat ose steril di permukaan media kombinasi. Jamur endofit yang telah tumbuh pada media MEA (Malt Extract Agar) kemudian dipotong membentuk bulat dan diletakkan pada media kombinasi MEA (Malt Extract Agar) dan MHA (Mueller Hinton Agar) yang telah digoresi bakteri uji. MHA ditimbang sebanyak 1,9 gram dan MEA ditimbang sebanyak 1,25 gram, selanjutnya dilarutkan dalam $100 \mathrm{ml}$ akuades. Media tersebut disterilisasi di autoclave dengan suhu $121^{\circ} \mathrm{C}$, kemudian tuang pada cawan petri, yang kemudian digunakan sebagai media kombinasi.

\section{Uji Kemampuan Daya Hambat Jamur Endofit dan Pengukuran Zona Hambat}

Penanaman jamur di media kombinasi MEA (Malt Extract Agar) dan MHA (Mueller Hinton Agar) dilakukan masingmasing 3 sampel jamur yang sama di 3 tempat pada 1 cawan petri. Sebagai kontrol positif diberikan larutan kloramfenikol 0,02 $\mathrm{mg} / \mathrm{ml}$ pada kertas saring dan diletakkan di tengah-tengah media, selanjutnya diinkubasi pada suhu kamar $\left(25^{\circ} \mathrm{C}\right)$. Setelah 24 jam dengan menggunakan penggaris milimeter dilakukan pengukuran diameter zona hambat, yaitu zona bening yang terbentuk di sekitar jamur endofit dan kertas saring. Pengukuran zona hambat dilakukan menggunakan penggaris dengan cara membalik cawan petri media kombinasi dan mengukur diameter daerah jernih. Terdapat daerah jernih di sekeliling media pertumbuhan bakteri uji yang tidak ditumbuhi bakteri. Diameter zona hambat diukur dalam satuan milimeter

\section{HASIL PENELITIAN}

Dari potongan daun Sonneratia alba telah berhasil diperoleh 2 isolat jamur endofit yang ditanam pada media MEA (Malt Extract Agar). Secara makroskopik jamur tipe I memiliki karakteristik yaitu miselia berwarna coklat sedangkan jamur tipe II memiliki miselia berwarna putih. Diameter zona hambat yang terbentuk dari kedua jamur endofit dapat dilihat pada Gambar 1.

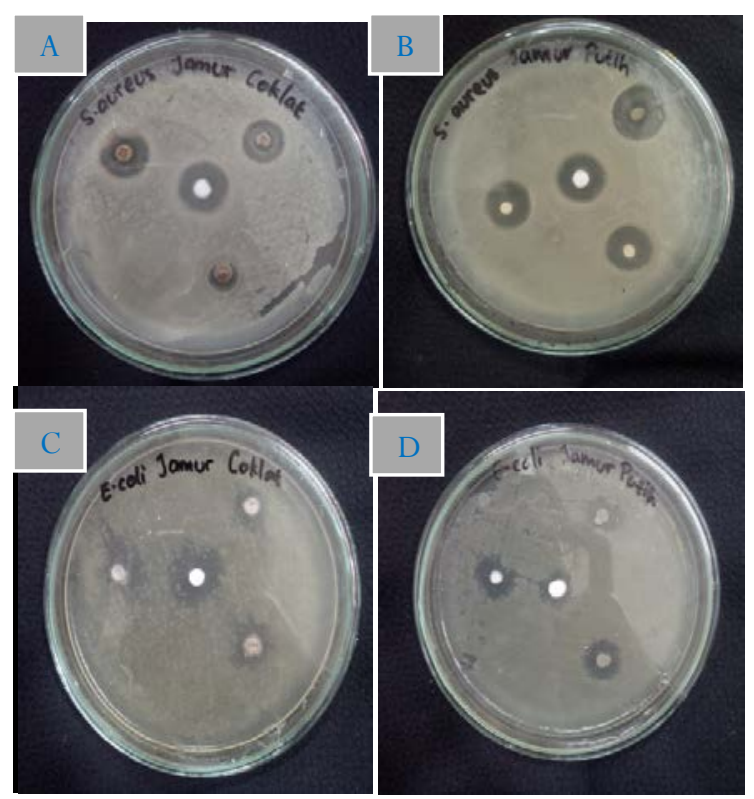

Gambar 1. A. Diameter zona hambat jamur endofit miselium coklat terhadap bakteri $S$. aureus, B. Diameter zona hambat jamur endofit miselium putih terhadap bakteri $S$. aureus, C. Diameter zona hambat jamur endofit miselium 
coklat terhadap bakteri E.coli, D. Diameter zona hambat jamur endofit miselium putih terhadap bakteri E.coli.

Tabel 1: Hasil uji efek antibakteri jamur endofit terhadap pertumbuhan bakteri Staphylococcus aureus.

\begin{tabular}{cccc}
\hline Sampel & Jamur & endofit & Kontrol + \\
\cline { 2 - 3 } & coklat & putih & \\
\hline a & 20 & 19 & 18 \\
b & 19 & 20 & \\
c & 14 & 17 & \\
Rata-rata & 17,6 & 18,6 & 18 \\
\hline
\end{tabular}

Tabel 2: Hasil uji efek antibakteri jamur endofit terhadap pertumbuhan bakteri Escherichia coli.

\begin{tabular}{ccccl}
\hline Sampel & \multicolumn{3}{c}{ Jamur } & endofit \\
\cline { 2 - 5 } & coklat & kontrol & putih & kontrol \\
\hline a & 10 & 19,3 & 15,2 & 12,4 \\
b & 13,6 & & 13,2 & \\
c & 15,6 & & 11,8 & \\
Rerata & 13 & 19,3 & 13,4 & 12,4 \\
& & & & \\
\hline
\end{tabular}

\section{BAHASAN}

Dari daun mangrove Sonneratia alba telah diisoloasi 2 spesies jamur endofit dengan karakteristik miselia berwarna coklat dan miselium berwarna putih. Isolat tersebut selanjutnya diujikan pada 2 spesies bakteri uji yaitu Staphylococcus aureus dan bakteri Escherichia coli untuk melihat daya hambat terhadap pertumbuhan bakteri tersebut diatas.

Berdasarkan hasil pengujian kemampuan hambat jamur endofit yang terdapat pada daun mangrove Sonneratia alba terhadap bakteri uji Staphylococcus aureus dan Escherichia coli menunjukan adanya daya hambat pertumbuhan bakteri. Pada pengukuran diameter zona hambat pada kedua isolat jamur diperoleh rata-rata daya hambat jamur endofit berwarna putih lebih besar dari pada jamur berwarna coklat. Daya hambat jamur putih lebih besar dapat dikarenakan jamur putih menghasilkan kandungan senyawa yang memiliki efek antibakteri yang lebih kuat dari pada jamur berwarna coklat. Jamur endofit berwarna putih memiliki daya hambat yang hampir sama dengan kontrol positif. Jamur berwarna putih belum diketahui mekanisme kerja peghambatan bakteri, karena sejauh ini belum ada penelitian yang mengisolasi kandungan antibakteri yang diproduksi jamur endofit tanaman ini. Kemungkinan komponen kimia aktif yang terdapat dalam tumbuhan mangrove yang berupa tanin, saponin, flavonoid dan kuinolon yang dihasilkan oleh endofit sebagai senyawa bersifat sebagai antibakteri.

\section{SIMPULAN}

Berdasarkan hasil pengujian jamur endofit yang diisolasi dari daun mangrove Sonneratia alba terhadap bakteri Staphylococcus aureus dan bakteri Escherichia coli, maka disimpulkan bahwa jamur endofit yang diisolasi dari daun mangrove Sonneratia alba memiliki aktivitas yang berpotensi menghambat pertumbuhan bakteri uji Staphylococcus aureus dan Escherichia coli.

\section{SARAN}

Perlu dilakukan penelitian lebih lanjut untuk mengidentifikasi senyawa yang berkhasiat anti pertumbuhan bakteri pada jamur endofit yang diisolasi dari tumbuhan Mangrove Sonneratia alba, mekanisme kerja anti pertumbuhan bakteri pada jamur endofit daun Mangrove Sonneratia alba dan perlu penelitian lebih lanjut tentang kemampuan daya hambat pertumbuhan bakteri menggunakan jamur endofit yang diisolasi dari bagian lain tumbuhan Mangrove Sonneratia alba.

\section{DAFTAR PUSTAKA}

1. Radji M. Peranan Bioteknologi Dan Mikroba Endofit Dalam Pengembangan Obat Herbal. Mikrobiologi. Majalah Ilmu Kefarmasian. 2005; 2(3): 11

2. Pusat Komunikasi Publik, Sekretariat Jendral Kementrian Kesehatan RI. Integrasi Pengobatan Tradisional Dalam Sistem Kesehatan Nasional. 02 November 2011 [diakses 26 Januari 2015]. Available from : 
http://www.depkes.go.id/article/print/ 1706/integrasi-pengobatan-

tradisional-dalam-sistem-kesehatannasional.html

3. Madjowa V. Identifikasi Tanaman Obat Dari Pesisir Pulau Mantehage. [skripsi].[Manado]: Universitas Sam Ratulangi; 1999

4. Prihanto AA. Aktivitas antibakteri akar mangrove Sonneratia caseolaris dan Penicillium sp. R1M terhadap Staphylococcus aureus dan Eschericia coli. 2nd National Conference on Green Technology EcoTechnology For Sustainable Living. Teknologi Hasil Perikanan. Malang: Universitas Brawidjaya
5. Strobel GA. Natural products from endophytic microorganism. Journal of Natural Products 2004 ; 67:257-268.

6. Tanaka M, Sukiman H, Takebayashi M, Saito K, Suto M, Prana MS, dan Tomita F, 1999. Isolation, Screening and Phylogenetic Identification of Endophytes from Plants in Hokaido Japan and Java Indonesia. Microbes and Environment 14(4):237-241.

7. Taechowisan T, Lu C, Shen Y, Lumyong S. 4-Arylcoumarins from endophytic Streptomyces aurefaciens CMUAc130 an their antifungal activity.2005;55(1):63-66. 